\title{
Ovine haemonchosis: a review
}

\author{
Muhammad Naeem $^{1} \cdot$ Zahid Iqbal $^{2}$ (I) $\cdot$ Nabila Roohi $^{1}$
}

Received: 3 June 2020 / Accepted: 6 October 2020 / Published online: 20 November 2020

(C) Springer Nature B.V. 2020

\begin{abstract}
Sheep farming is the backbone of a rural economy in developing countries, and haemonchosis is a major impediment in the way of its progress. Haemonchus contortus (H. contortus) infection persists all over the world particularly in the tropical and subtropical regions. Various review articles have been published to substantially cover one or more aspects of its morphology, prevalence, pathogenesis, symptoms, diagnosis, immune response, drug resistance, treatment, and control measure. The objective of this paper is to briefly review past and present information available in the aforementioned areas in one place to enable the readers to fully understand the problem from a broader perspective. H. contortus parasite harbours in abomasum of affected animal and feeds on its blood, producing mild to severe symptoms and even death in acute form. The parasite thus inflicts heavy production losses and is of economic importance. $H$. contortus has developed diverse characters over the years leading to limited success in the production of vaccines. Indiscriminate use of the anthelmintics has produced drug resistance against almost all conventional products. Efficacy of medicinal plants and non-conventional chemicals has been reported under controlled experiments; however, research on their adverse effects on growth and fertility is yet to be studied. Research on molecular tools for identification and introduction of resistant genes into the flock is also underway but still a long journey to find its field application. Crossbreeding may compromise the production traits of the existing flock. In given circumstances, a targeted selective treatment approach along with selective breeding, culling of more susceptible animals, and maintaining a good body condition score through the provision of a balanced diet remains a workable strategy to control haemonchosis in sheep.
\end{abstract}

Keywords Haemonchosis $\cdot$ Sheep $\cdot$ Barber's pole worm $\cdot$ Ovine

\section{Introduction}

In developing countries, the livestock sector is considered the backbone of the economy, and the small ruminants, including ovine, make its major segment (FAOSTAT 2018). Sheep are reared in rural areas for sale in the open market as a valuable source of organic meat throughout the year. Farmers, dealers, and the state also generate handsome revenue through its trading as sacrificial food animals at the occasion of annual religious festivals in Muslim countries. The demand is rapidly multiplying because of fast growth in population, increased buying power of people, and export opportunities (Rehman et al. 2017; Bai et al. 2020). Wool, skin, and hide are other by-

Zahid Iqbal

zahidzizi@gmail.com

1 Department of Zoology, University of the Punjab, Lahore, Pakistan

2 Cattle Breeding Area, Sahiwal, Pakistan products of this industry which significantly contribute to local as well as an export market and fetch valuable foreign exchange. Sheep milk and related dairy products also have potential in the human food market due to its peculiar health benefits (Balthazar et al. 2019; Mohapatra et al. 2019). In tropical regions, sheep farming is carried out under a semiextensive system (Chaudary et al. 2007; Kandiwa et al. 2020) where flocks of all age groups are taken out during the day for grazing in harvested fields, along the roadside, canal banks, and foothills. Water available in stagnant reservoirs and irrigation channels is offered for drinking. Night housing consists of mud-erected sheds and paddocks. This system coupled with a high temperature-humidity index naturally exposes the animals to infestation with several gastrointestinal parasites (Swarnkar and Singh 2020; Vohra et al. 2020) which increases their susceptibility to other ailments as well. Among these parasites, Haemonchus contortus (H. contortus) is the most prevalent species which adversely affects the health of sheep leading to lower production. Commonly found effects are loss of appetite, impaired feed utilization, stunted growth, 
weakness, anaemia, poor fertility, and even death of lambs which cause major economic losses to the farmers (Emery et al. 2016; Iliev et al. 2017; Goel et al. 2020). The prevalence of $H$. contortus is around the, globe and even temperate zones are not safe due to its adapted strains (Sallé et al. 2019). Several studies and research works have been carried out on $H$. contortus infection in sheep covering various aspects of its prevalence, life cycle, pathogenesis, clinical symptoms, diagnostic methods, host immunity, treatment, control measures, and drug resistance. However, even today, this nematode remains an impediment in the way of the desired production in sheep farming. The situation demands the collection of a compendious knowledge about $H$. contortus at one place to make it readily understandable for the reader. The objective of the current article is to carry out a comprehensive review of scientific information available in the aforementioned study areas of $H$. contortus to serve as a guideline for people engaged in the sheep husbandry sector.

\section{Morphology}

$H$. contortus is a nematode parasite of family Trichostrongylidae later classified as Haemonchidae (Palevich et al. 2019). Figure 1 shows its main morphological features. The adult parasite has an anteriorly tapering cylindrical body (Widiarso et al. 2018). A small oral cavity is equipped with a prominent lancet type tooth on the dorsal side for sucking capillary blood from the host stomach wall (Sambodo et al. 2018; Widiarso et al. 2018). The organism is whitish yellow in colour; however, ingested blood gives it a reddish appearance. The male bears a lobulated genital bursa at the tail end, a gubernaculum, and a pair of needle-like spicules for mating (Kuchai et al. 2012; El-Ashram and Suo 2017; Melnychuk 2019). Female has vulvular pouches towards posterior end covered with a prominent linguiform, smooth, or knobbed process (Irfan-ur-Rauf et al. 2014; Nahar et al. 2019). The blood-filled intestine in the female with the white uterus, winding around, gives the shape of a "barber's pole", the popular name used for this parasite (Saminathan et al. 2015) (Fig. 1). The average length of the male is $10-20 \mathrm{~mm}$ and that of the female is $18-30 \mathrm{~mm}$ (Roeber et al. 2013a). The eggs at an average are 70-79 $\mu \times 45-49 \mu$ in size (Mahmood et al. 2019). Genetic variation has given rise to so many strains of H. contortus (Yin et al. 2016; Sargison et al. 2019).

\section{Prevalence}

As per the latest information available, $H$. contortus originated from sub-Sahara, Africa, in wild ungulates and then evolved to spread across the globe through the movement of host

Fig. 1. H. contortus. (a) Eggs. (b) $\mathrm{L}_{3}$ larva with tapering end. (c) Adult female, the arrow is pointing to vulval flap. (d) Adult male, the copulatory bursa (1) spicules (2) (El-Ashram and Suo 2017)

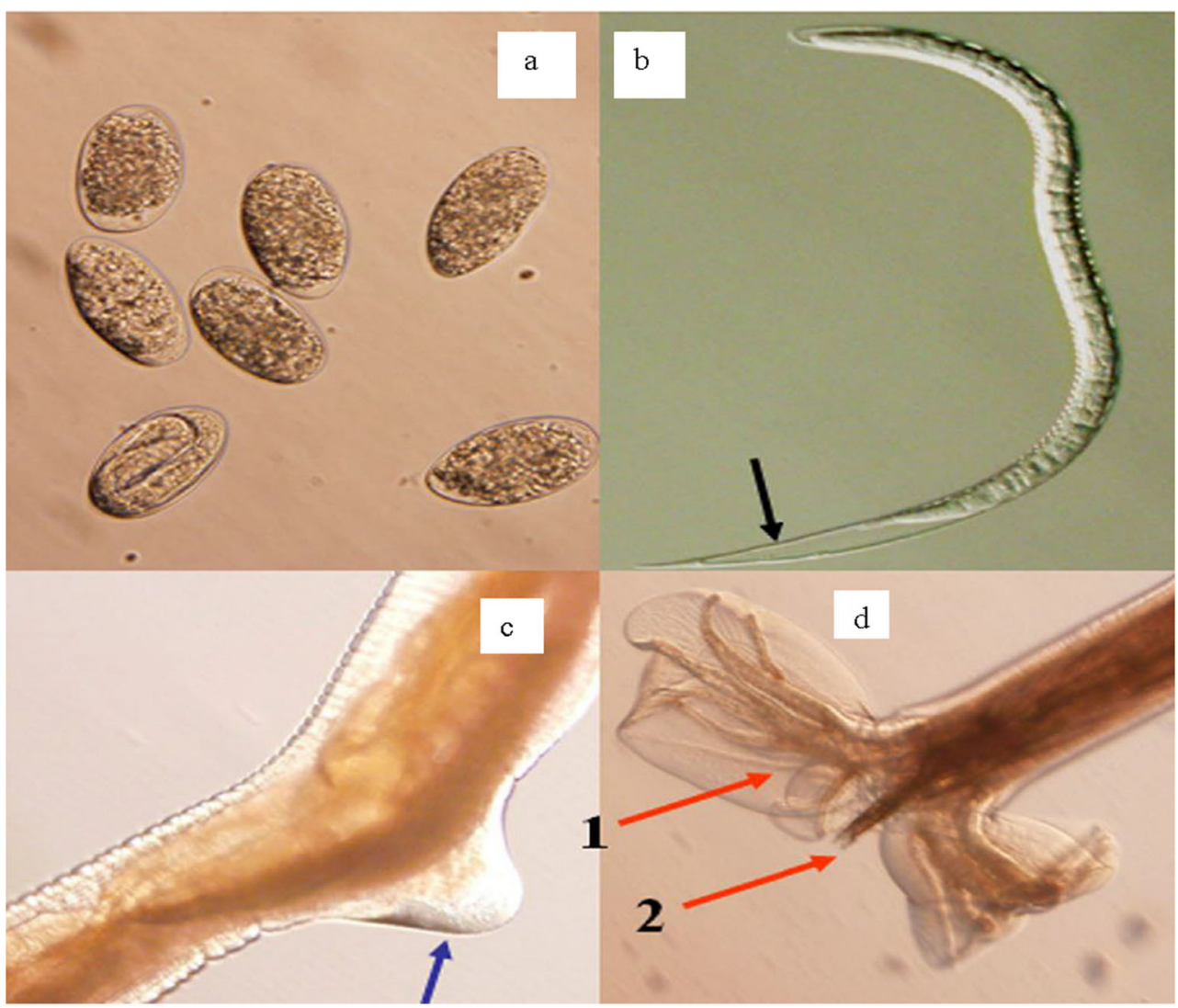


animals and human intervention (Gilleard and Redman 2016; Sallé et al. 2019). All classes of ruminants are susceptible; however, aggressive distribution has been noticed in sheep and goat population (Yin et al. 2016). The parasite finds highly favourable warm and wet conditions in tropical and subtropical countries (O'Connor et al. 2006); however, over the years, prevalence has also been reported from temperate regions due to climatic changes (Emery et al. 2016; Rose et al. 2016). Incidence may vary with season, area, age, sex, breed, and body condition; however, findings of such studies are not consistent. The average larval establishment rate has been reported to be $0.24 \pm 0.02$ (Saccareau et al. 2017). Random examination of abomasums from abattoirs in Ethiopia (Tesfaheywet and Murga 2019) and faecal egg count (FEC) from the farms in Rwanda (Mushonga et al. 2018) revealed over $80 \%$ prevalence in sheep.

\section{Life cycle}

H. contortus passes through six stages of life which include egg, four larval stages, and the adult (El-Ashram and Suo 2017) (Fig. 2). Typical to its family, the female parasite lays numerous eggs with an average $( \pm \mathrm{SE})$ of $1295.9 \pm 280.4$ per day which are passed through faeces to pastures (Saccareau et al. 2017). The eggs may die or develop to free-living larval 1st stage $\left(\mathrm{L}_{1}\right)$, 2nd stage $\left(\mathrm{L}_{2}\right)$, and infective stage $\left(\mathrm{L}_{3}\right)$ within 1-7 (Schwarz et al. 2013) days. The hatchability of eggs and development to infective larvae depend upon the availability of suitable environmental conditions (temperature range of $15-37^{\circ} \mathrm{C}$ and relative humidity of $85-100 \%$ ) in faecal pellets and herbage (O'Connor et al. 2006). Stage $\mathrm{L}_{3}$ is ingested by the host where it undergoes ensheathment in the rumen and takes 2-3 weeks to develop into parasitic stage $\mathrm{L}_{4}$. After two moultings and just before the final moult, immature adult $\mathrm{L}_{5}$ erupts which develops a lancet to penetrate the mucosal vessels for sucking blood. The abomasum is the predilection site where the adult worms move freely. The parasite may also undergo arrested inactive phase of development in the host animal during winter called hypobiosis (Zajac and Garza 2020).

\section{Pathogenesis and symptoms}

Degree of the establishment of $H$. contortus and consequent sickness depend upon the number of infective larvae ingested, age (Saccareau et al. 2017), immunity level, and nutritional status of the host. Major pathogenic damage occurs due to the sucking of blood by the free-living parasites and eruption of ulcerative lesions in the abomasal mucosa leading to digestive syndrome and anaemic disorders (Besier et al. 2016b). The infected sheep may lose up to $30 \mu \mathrm{L}$ of blood every day due to one parasite and even death in the pre-patent period (Emery et al. 2016). Loss of blood which is either ingested or let oozed out from the mucosal lesion to faeces leads to anaemia, which appears 10-12 days after getting infected (Roeber et al. 2013b), and a fall in packed cell volume (PCV) (Storey et al. 2017; Ferreira et al. 2019) detectable even at 4th day. The PCV value further drops by 3-6 weeks due to increased blood loss by the accelerated activity of parasites and bleeding from haemorrhagic gastritis lesions. A concurrent reduction in

\section{L4 moults to adult in host stomach}

L3 ingested by the grazing host
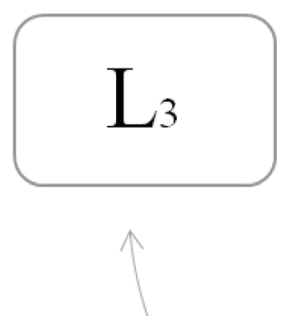

\section{Eggs passed into faeces}

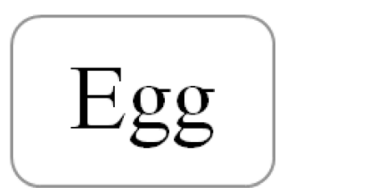

L2 moults to L3 which moves to pasture

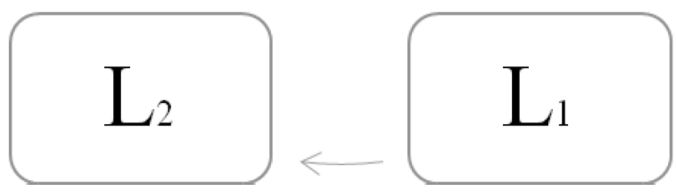

L1 moults to L2 in faeces

Fig. 2 Life cycle effect of $H$. contortus. Eggs hatch to L1 in faeces, L1 moults to L2 in faeces, and eggs passed into faeces 
the concentration of haemoglobin and plasma protein is also observed (Swarnkar and Singh 2018). Extensive damage to abomasal mucosa affects the passage rate of ingesta, produces pain and inflammatory cytokines, and changes in gastric secretions as well as the level of gastrointestinal hormones in plasma which lead to prolonged loss of appetite (AnguloCubillán et al. 2007). Due to raised pH of the abomasum, rumen microbes do not get inactivated and lysed resulting in the non-availability of amino acids. Physical and chemical damage caused by the parasite induces the inflammatory response in the gastric tissues leading to a collection of numerous neutrophils, lymphocytes, and eosinophils which further aggravate the situation (Alam et al. 2020). Clinically haemonchosis can be sub-divided into hyper-acute, acute, and chronic forms. In a hyper-acute case, sudden death is the only sign. Acute form involves severe anaemia, lethargy, weakness, increased respiratory and heart rate, dark mushy faeces, loss of wool, pale to white conjunctiva, ascites, and sub-mandibular and cervical oedema. Quite recently fatal outbreaks of haemonchosis in lambs have been reported (Paul et al. 2020). Chronic disease is characterized by anorexia, loss of weight, agalactia, pallor of the conjunctiva, and mucosa (Besier et al. 2016b; Iliev et al. 2017).

\section{Diagnosis}

Diagnosis of haemonchosis can be made through the clinical picture, FAfa MAlan CHArt (FAMACHA), morphological identification of eggs and parasite, molecular techniques, haematology, immunological procedures, and post-mortem findings (Besier et al. 2016a; Zarlenga et al. 2016). FAMACHA is a popular method in tropical and sub-tropical countries which involves visual assessment of anaemia through watching colour of conjunctiva on a score of $1-5,1$ and 2 (red or pink) being normal, 3 (light pink) doubtful, and 4 and 5 (pale) being anaemic (Ferreira et al. 2019). FAMACHA scores 4 and 5 with blood PCV value $\leq 15 \%$ have been found highly sensitive, whereas scores $3-5$ with PCV value $\leq 18 \%$ have been found highly sensitive for the diagnosis of haemonchosis in sheep (Ferreira et al. 2019); however, variation due to breed has been reported (Alam et al. 2020). Each diagnostic method has its limitation and advantages. Various techniques used have been reviewed in Table 1 .

\section{Immune response}

$H$. contortus-infective larvae and adults, while feeding on blood in the abomasum of the host animal, also release antigenic secretions and excretions which are glycoprotein in nature. Exposure to these antigens stimulates the immune system of the host leading to activation of inflammatory, humoral, and cellular responses to reject the invading parasites (Emery et al. 2016). A large number of helper T cells appear in abomasum of $H$. contortus-infected sheep. Getting stimulated by the specific antigen, they release messenger cytokines, mostly the interleukins. These cytokines activate eosinophils, mastocytes, and globule leukocytes in peripheral mucosal tissue that is infection site as well as in blood (Robinson et al. 2010). Followed by this immediate response, the cytokines also activate $\mathrm{B}$ cells resulting in the production and release of infection-specific antibodies $\operatorname{IgA}$ and $\operatorname{IgG} 1$ into serum, mucosa, and saliva (Hernandez et al. 2016; Escribano et al. 2019). The mastocytes and eosinophils release inflammatory substances like histamines, proteases, leukotrienes, and prostaglandins. These mediators enhance the production of mucus, paralyse and kill the parasite, intensify smooth muscle contractions for removal of the parasite, inhibit the further establishment of third-stage larvae, and reduce egg production (Angulo-Cubillán et al. 2007; Escribano et al. 2019). Resistance level has been known to vary among various breeds and lines of sheep as resistant animals have shown a potent parasite-specific local and systemic immune response (Escribano et al. 2019). Cross-protective and added immunity has also been reported in animals previously exposed to mixed infections (González-Garduño et al. 2018).

\section{Treatment}

There are various strategies for the treatment of $H$. contortus on herd level. One common practice is periodical deworming of all the flocks with anthelmintic drugs. This approach is costly, offers the least opportunity for the development of immune response in the growing flock, and also potentiates the risk of parasite resistance. An alternate approach is targeted treatment (TT) where a targeted flock is treated with anthelmintics and others are allowed to graze on infected pastures. Another regime with a reduced cost of treatment is targeted selective treatment (TST) in which only selected animals are treated leaving remaining flock as such presumably being healthy or bearing less resistant worms, to have epidemiological benefits (Kenyon and Jackson 2012; Calvete et al. 2020). Last two strategies are labour intensive and based on inspection of individual animals, by the skilled technicians for anaemia score (FAMACHA), body condition score (BCS) (Cornelius et al. 2014), faecal egg count, or live weight gain measurement (Greer et al. 2009; Kenyon and Jackson 2012). Anthelmintics are the most commonly used drugs for the treatment of $H$. contortus throughout the world which still have adequate efficacy (Calvete et al. 2020), but the need for the choice of an effective anthelmintic to prevent the development of resistance cannot be overemphasized. Broad-spectrum substances like benzimidazoles (albendazole), imidazothiazole, and macro-cyclic lactones (ivermectin) have been known to 
Table 1 Diagnostic methods

\begin{tabular}{|c|c|c|c|}
\hline Procedure & Technique & Advantage, limitation & Reference \\
\hline Clinical symptoms & $\begin{array}{l}\text { History, examination, body condition score, } \\
\text { anaemia score (FAMACHA), faecal score }\end{array}$ & $\begin{array}{l}\text { Practicable in the field, } \\
\text { non-specific }\end{array}$ & $\begin{array}{l}\text { Taylor et al. (2007), Besier et al. (2016b), } \\
\text { Zarlenga et al. (2016), Ferreira et al. } \\
\text { (2019) }\end{array}$ \\
\hline $\begin{array}{l}\text { Faecal egg count and } \\
\text { identification }\end{array}$ & $\begin{array}{l}\text { McMaster method and its modifications, lectin } \\
\text { staining, automated egg examination, } \\
\text { FLOTAC }\end{array}$ & Easier, non-specific & Cringoli et al. (2010), Paras et al. (2018) \\
\hline $\begin{array}{l}\text { Larval culture, egg } \\
\text { hatch test }\end{array}$ & Faecal incubation and identification of larvae & $\begin{array}{l}\text { Laborious, not suitable for } \\
\text { mixed infections }\end{array}$ & $\begin{array}{l}\text { Coles et al. (2006), Zarlenga et al. (2016), } \\
\text { Aguilar-Marcelino et al. (2020) }\end{array}$ \\
\hline $\begin{array}{l}\text { Immunological } \\
\text { detection }\end{array}$ & $\begin{array}{l}\text { ELISA, CFT, indirect-immunofluorescence, } \\
\text { indirect haem-agglutination }\end{array}$ & $\begin{array}{l}\text { Non-specific, cannot } \\
\text { differentiate old and } \\
\text { current infection }\end{array}$ & Hassan et al. (2019) \\
\hline $\begin{array}{l}\text { Visible-near infrared } \\
\text { spectroscopy for } \\
\text { detection } \\
\text { of blood in sheep faeces }\end{array}$ & $\begin{array}{l}\text { Detecting the presence of haemoglobin in sheep } \\
\text { faeces }\end{array}$ & $\begin{array}{l}\text { Non-specific, possible on a } \\
\text { farm }\end{array}$ & Kho et al. (2020) \\
\hline $\begin{array}{l}\text { PCR, Droplet digital } \\
\text { PCR }\end{array}$ & $\begin{array}{l}\text { Real-time PCR after DNA extraction from egg } \\
\text { flotation of faecal samples }\end{array}$ & $\begin{array}{l}\text { Specific, expensive, difficult } \\
\text { in the field }\end{array}$ & $\begin{array}{l}\text { Zarlenga et al. (2016), Elmahalawy et al. } \\
\text { (2018), Höglund et al. (2019) }\end{array}$ \\
\hline $\begin{array}{l}\text { Post-mortem } \\
\quad \text { examination }\end{array}$ & $\begin{array}{l}\text { Washing of organ and sieving, identification and } \\
\text { counting of worms }\end{array}$ & Specific & Besier et al. (2016a) \\
\hline
\end{tabular}

Elisa enzyme-linked immunosorbent assay, $C F T$ complement fixation test, $P C R$ polymerase chain reaction

create resistant parasite strains (Chaparro et al. 2017; dos Santos et al. 2019; Duarte et al. 2019). The combined use of more than one anthelmintic has been found adequately effective against resistant parasites (Borges et al. 2020). Longacting products are though potentially effective (Ballent et al. 2019) but also have a risk of resistance development (Leathwick et al. 2006). Nevertheless, narrow-spectrum anthelimintics appear to be a better choice if they are used with absolute care. An alternate approach is to carry out 'faecal egg count reduction test' (FECRT) before choosing an anthelimintic (Salgado et al. 2019). However, an even better, time-saving, economical, and standard strategy is to carry out DNA-based testing regionally to identify resistant strains of H. contortus against a range of drugs (Ehrenreich et al. 2012). Studies have also been conducted to check the efficacy of other non-conventional compounds of plant origin (Zamilpa et al. 2019; Mravčáková et al. 2020) with variable success and preferred because of their non-residual effect in meat and milk. Few other substances like anti-protozoan drugs (Nixon et al. 2019), heterocyclic compounds (Nguyen et al. 2019), and organophosphate (Duarte et al. 2019) previously not used due to their toxicity have also been tried against resistant strains of $H$. contortus with success.

\section{Parasite resistance}

H. contortus has tremendous capability to develop resistance against almost all classes of anthelmintics and their combinations (Lyndal-Murphy et al. 2014), which is a major threat for sheep production through the world. This has happened due to the indiscriminate use of these chemicals leading to genetic mutations producing phenotypic variations (Chaudhry et al. 2015). Fast adaptation by this nematode to variations in climate and species of the host has also been reported (Troell et al. 2006). Elaborate information on the underlying mechanism of genetic diversification has been published (Gilleard and Redman 2016). Fortunately, the whole genome sequence of $H$. contortus has been read, and it is possible to accurately diagnose resistant strains basing on DNA testing which can make a sound basis for vaccine development (Wang et al. 2017).

\section{Control}

Due to constantly increasing drug resistance in $H$. contortus and residual effects, the control strategies which employ minimal use of synthetic anthelmintics have gained importance in the sheep industry. The experts have recommended an integrated control mechanism encompassing various approaches instead of relying on a single option to achieve enough control (Fernandes et al. 2019). Management fields like the selection of resistant lines of sheep, adoption of grazing techniques, and vaccination program have also gained significant attraction. A brief account of various control measures is given in the following sub-paras.

\section{Pasture management}

Across the globe, sheep are raised under extensive systems relying on pasture grazing. The underlying principle of this 
control segment is to minimize contact with infective larvae $\left(\mathrm{L}_{3}\right)$ of $H$. contortus. For this purpose, various grazing techniques have been suggested. Rotational grazing, a commonly employed practice (Whitley et al. 2014), involves the introduction of the flock to a field when the bulk of $\mathrm{L}_{3}$ larvae has naturally diminished but such tactics are not successful in temperate countries where this stage has long survival period (Eysker et al. 2005). This system compromises the availability of forage by missing ideal periods. Cell grazing system which involves grazing of the sheep on a limited patch with high stocking density has been known to be equally effective in reducing faecal egg count of grazed animals (Ruiz-Huidobro et al. 2019). Mixed grazing of more than one host simultaneously or alternately presumably restricts the consumption of infective larvae by the specific host (Mahieu and Aumont 2009). Parallel to these interventions, H. contortus is also undergoing selective adaptations in its developmental and reproductive stages resulting in long inhibitive stages in the host and prolonged survival period of eggs at pastures.

\section{Nutritional management}

Provision of a well-balanced, nutritionally supplemented diet in sufficient quantity to sheep especially during late pregnancy and also to the growing lambs is an essential part of control strategies (Macarthur et al. 2014). Quality nutrition adds to the expression of resistance and resilience of host, through the provision of additional nutrients, even under infected conditions. Diet supplemented with high protein (Rocha et al. 2011), amino acids like methionine and leucine (Sakkas et al. 2013), and rumen-protected protein (Cériac et al. 2019) have been shown to boost immunity, decrease parasite proliferation, maintain production, and reduce FEC under infective conditions.

\section{Selective breeding}

Immunity against $H$. contortus expressed as FEC and PCV values is a heritable trait in sheep (Becker et al. 2020), and differences among breeds to resist infection have been known to exist. One practicable and phenotypic way is the culling of susceptible and selection of resistant animals within a flock (Gowane et al. 2020); however, it is a long-term and laborious strategy. Resistant alleles have been identified in some breeds like Red Maasai (Benavides et al. 2015; Estrada-Reyes et al. 2019), and introgression of these foreign genes through crossbreeding is an attractive workable option but should be done with utmost care so that production traits of the existing flock are not compromised. Another possible futuristic technology is the production and introduction of a sufficient number of transgenic animals having the capacity to withstand infection (Emery et al. 2016).

\section{Vaccination}

Vaccination development using $H$. contortus larval antigen has been tried with success in the shape of reduction in FEC and lower worm burden in experimentally challenged animals (Fawzi et al. 2015). A commercial vaccine 'Barbervax' was released in Australia which has proved its efficacy in field trials (Besier et al. 2015); however, the production of its recombinant subunits has yet not been successful (Nisbet et al. 2016). Quite recently recombinant vaccine produced from $H$. contortus transthyretin domain-containing protein has been reported to induce partially protective immune responses against $H$. contortus infection (Tian et al. 2020). It is to be kept in mind that $H$. contortus has great genetic diversification (Gilleard and Redman 2016), and it may modify its antigenic structure to withstand the immune response of the host.

\section{Targeted selective treatment}

As also described in the treatment section, this system involves administering treatment to only selected animals in the flock with an anthelmintic based on periodical examination. It saves expenditures on drugs and helps to identify susceptible animals for culling (Terrill et al. 2012). The simplest technique is 'FAMACHA' in which lower eyelid of the animal is inspected to determine the degree of anaemia reflective of worm burden (Prashanth et al. 2020).

\section{Biological control}

A number of studies on biological control of $H$. contortus have been carried out. DE et al. (2016) described a larvicidal action of toxins released by the bacteria 'Bacillus thuringiensis' against $H$. contortus which resulted in significant reduction of larvae in faecal culture after oral drench to infected lambs. Similar results were found by using spores suspension of Bacillus circulans (Sinott et al. 2016). Nematophagous or nematocidal action of metabolites from various fungi has also been exploited positively which has the potential to be used against $H$. contortus (de Gives and Braga 2017; Liu et al. 2020). A leguminous plant Sericea lespedeza, when grazed (fresh) on pastures or fed as hay (ground or pelleted), significantly reduced FEC of infected animals (Dykes et al. 2019).

\section{Biosecurity}

Strict biosecurity measures are required to prevent the introduction of resistant strains of the parasite to the flock. 


\section{Non-conventional compounds}

Some non-conventional compounds with anthelmintic effects have been suggested as part of the control mechanism. Copper oxide wire particles initially used as a mineral supplement are now well-known to be effective against $H$. contortus in weaning lambs without any toxic effect (Schweizer et al. 2016; Fetene and Amante 2019). Several studies have advocated the role of condensed tannin content of various forage plants used as 'nutraceuticals' in controlling gastrointestinal parasites of sheep including $H$. contortus (Pathak et al. 2016; Mata-Padrino et al. 2019). A recent study in Pakistan found the extract of 'Neem tree (Azadirachta indica) leaves' highly effective against $H$. contortus under laboratory conditions (Azra et al. 2019) due to its polyphenolic flavonoids content. Another most recent study found a significant inhibition of hatchability of $H$. contortus eggs with the use of saponins extracted from forage plants of 'Medicago' species (Maestrini et al. 2020). The sheep experimentally infected with $H$. contortus and supplemented with yeast Saccharomyces cerevisiae for a period of 49 days showed a significant reduction of larvae and a higher number of circulating antibodies (Pinto et al. 2020).

\section{Chemoprophylaxis}

This control mechanism involves prophylactic administration of anthelmintics to all the animals during high prevalence periods of the year. This practice is more commonly adopted in tropical regions where the flocks are dewormed with regular intervals during the rainy season with a suitable product available. However, their prolonged use at a sub-lethal dose is leading to poor efficacy and development of drug resistance in the parasite (Getachew et al. 2007; Kellerová et al. 2020).

\section{Conclusion}

Haemonchosis remains a major problem in the sheep industry across the world. The organism has adapted to survive under diverse climatic conditions. Resistance has been reported against the latest available anthelmintics. Alternate compounds also have limited efficacy, and their effects on production parameters are least known. Biological control measures have their constraints. Due to diverse antigenic strains of the parasite, the recombinant production of vaccines is yet a challenge for researchers. Under these circumstances, targeted selective treatment along with culling of more susceptible animals and maintenance of good body condition score through the provision of a nutritionally balanced diet is considered the best control strategy at the herd level. Meanwhile, the scientists engaged in its related fields should carry out extensive research for the development of a potent vaccine against all strains of $H$. contortus and find a therapeutic agent which should remain effective for decades without heaving residual effects.

\section{Compliance with ethical standards}

Conflict of interest The authors declare that they have no conflict of interest.

Ethical review This review does not involve any human or animal testing.

\section{References}

Aguilar-Marcelino, L., Mendoza-de-Gives, P., Torres-Hernández, G., López-Arellano, M.E., and González-Garduño, R., 2020. Butlerius butleri (Nematoda: Diplogasteridae) Feeds on Haemonchus contortus (Nematoda: Trichostrongylidae) Infective Larvae and Free-Living Nematodes in Sheep Faecal Cultures Under Laboratory Conditions: Preliminary Report, Acta Parasitologica. Accessed 5 June 2020 https://doi.org/10.2478/s11686-020-00216-Z

Alam, R.T., Hassanen, E.A., and El-Mandrawy, S.M., 2020. Heamonchus Contortus infection in Sheep and Goats: alterations in haematological, biochemical, immunological, trace element and oxidative stress markers, Journal of Applied Animal Research, 48, 357-364

Angulo-Cubillán, F.J., García-Coiradas, L., Cuquerella, M., De la Fuente, C., and Alunda, J.M., 2007. Haemonchus contortus-sheep relationship: a review, Revista Científica, 17, 577-587

Azra, A., Kaleemullah, M., Khattak, B., Asma, N., Safi, A., Qaiser, J., Afzal, M., Tahir, U., Sindhu, Z., and Farhan, Y., 2019. Comparative efficacy of domestic garlic (allium sativum) and neem (azadirachta indica) against haemonchus contortus in small ruminants, Applied Ecology and Environmental Research, 17, 10389-10397

Bai, J., Seale Jr, J.L., and Wahl, T.I., 2020. Meat demand in China: to include or not to include meat away from home?, Australian Journal of Agricultural and Resource Economics, 64, 150-170

Ballent, M., Maté, M.L., Dominguez, P., Virkel, G., Albérich, M., Lespine, A., Lanusse, C., and Lifschitz, A.L., 2019. Assessment of the long-acting ivermectin formulation in sheep: Further insight into potential pharmacokinetic interactions, Journal of Veterinary Pharmacology and Therapeutics, 42, 189-196

Balthazar, C., Santillo, A., Guimarães, J., Capozzi, V., Russo, P., Caroprese, M., Marino, R., Esmerino, E., Raices, R.S., and Silva, M., 2019. Novel milk-juice beverage with fermented sheep milk and strawberry (Fragaria $\times$ ananassa): Nutritional and functional characterization, Journal of Dairy Science, 102, 10724-10736

Becker, G., Davenport, K., Burke, J.M., Lewis, R.M., Miller, J., Morgan, J., Notter, D., and Murdoch, B., 2020. Genome-wide association study to identify genetic loci associated with gastrointestinal nematode resistance in Katahdin sheep, Animal Genetics, 51, 330-335

Benavides, M.V., Sonstegard, T.S., Kemp, S., Mugambi, J.M., Gibson, J.P., Baker, R.L., Hanotte, O., Marshall, K., and Van Tassell, C., 2015. Identification of novel loci associated with gastrointestinal parasite resistance in a Red Maasai x Dorper backcross population, PloS One, 10, e0122797

Besier, B., Kahn, L., Dobson, R., and Smith, D., 2015. Barbervax ${ }^{\circledR} — a$ new strategy for Haemonchus management. Proceedings of the Australian veterinary association (AVA) annual conferences, Pan Pacific (NZVA and AVA) Veterinary Conference, Combined Proceedings. Brisbane, 2015, 168-174 
Besier, R., Kahn, L., Sargison, N., and Van Wyk, J., 2016a. Diagnosis, treatment and management of Haemonchus contortus in small ruminants. Advances in Parasitology, 2016a, (Elsevier), 181-238

Besier, R., Kahn, L., Sargison, N., and Van Wyk, J., 2016b. The pathophysiology, ecology and epidemiology of Haemonchus contortus infection in small ruminants. Advances in Parasitology, 2016b, (Elsevier), 95-143

Borges, D.G.L., de Araújo, M.A., Carollo, C.A., Carollo, A.R.H., Lifschitz, A., Conde, M.H., de Freitas, M.G., dos Santos Freire, Z., Tutija, J.F., and Nakatani, M.T.M., 2020. Combination of quercetin and ivermectin: In vitro and in vivo effects against Haemonchus contortus, Acta Tropica, 201, 105213

Calvete, C., González, J.M., Ferrer, L.M., Ramos, J.J., Lacasta, D., Delgado, I., and Uriarte, J., 2020. Assessment of targeted selective treatment criteria to control subclinical gastrointestinal nematode infections on sheep farms, Veterinary Parasitology, 277, 109018

Cériac, S., Archimède, H., Feuillet, D., Felicite, Y., Giorgi, M., and Bambou, J.-C., 2019. Supplementation with rumen-protected proteins induces resistance to Haemonchus contortus in goats, Scientific Reports, 9, 1-10

Chaparro, J.J., Villar, D., Zapata, J.D., López, S., Howell, S.B., López, A., and Storey, B.E., 2017. Multi-drug resistant Haemonchus contortus in a sheep flock in Antioquia, Colombia, Veterinary Parasitology: Regional Studies and Reports, 10, 29-34

Chaudary, F., Khan, M., and Qayyum, M., 2007. Prevalence of Haemonchus contortus in naturally infected small ruminants grazing in the Potohar area of Pakistan, Pakistan Veterinary Journal, 27, 73

Chaudhry, U., Redman, E.M., Raman, M., and Gilleard, J.S., 2015. Genetic evidence for the spread of a benzimidazole resistance mutation across southern India from a single origin in the parasitic nematode Haemonchus contortus, International Journal for Parasitology, 45, 721-728

Coles, G., Jackson, F., Pomroy, W., Prichard, R., von SamsonHimmelstjerna, G., Silvestre, A., Taylor, M., and Vercruysse, J., 2006. The detection of anthelmintic resistance in nematodes of veterinary importance, Veterinary Parasitology, 136, 167-185

Cornelius, M., Jacobson, C., and Besier, R., 2014. Body condition score as a selection tool for targeted selective treatment-based nematode control strategies in Merino ewes, Veterinary Parasitology, 206, 173-181

Cringoli, G., Rinaldi, L., Maurelli, M.P., and Utzinger, J., 2010. FLOTAC: new multivalent techniques for qualitative and quantitative copromicroscopic diagnosis of parasites in animals and humans, Nature Protocols, 5, 503-515

de Gives, P.M., and Braga, F.R., 2017. Pochonia chlamydosporia: A Promising Biotechnological Tool Against Parasitic Nematodes and Geohelminths. Sustainability in plant and crop protection, 2017, (Springer), 371-383

De, A.P.D.S.S., Lorenzon, L.B., Vianna, A.M., SANTOS, F.D.S., Pinto, L.S., BERNE, M.E.A., and LEITE, F.P.L., 2016. Larvicidal activity of Bacillus thuringiensis var. israelensis Cry11Aa toxin against Haemonchus contortus, Parasitology, 143, 1665-1671

dos Santos, J.M.L., Vasconcelos, J.F., Frota, G.A., de Freitas, E.P., Teixeira, M., da Silva Vieira, L., Bevilaqua, C.M.L., and Monteiro, J.P., 2019. Quantitative molecular diagnosis of levamisole resistance in populations of Haemonchus contortus, Experimental Parasitology, 205, 107734

Duarte, E.R., Matias, A.D., Bastos, G.A., Maia, R.C., Júnior, V.S.M., Soares, A.C.M., dos Santos Magaço, F., de Oliveira, N.J.F., and Dos Santos, T.A.X., 2019. Anthelmintic efficacy of trichlorfon and blood parameters of young lambs infected with Haemonchus contortus, Veterinary Parasitology, 272, 40-43

Dykes, G., Terrill, T., Whitley, N., Singh, A., Mosjidis, J., Burke, J., and Miller, J., 2019. Effect of Ground and Pelleted Sericea Lespedeza Whole Plant and Leaf Only on Gastrointestinal Nematode and
Coccidial Infection in Goats, Journal of Agricultural Science and Technology A, 9, 93-102

Ehrenreich, I.M., Bloom, J., Torabi, N., Wang, X., Jia, Y., and Kruglyak, L., 2012. Genetic architecture of highly complex chemical resistance traits across four yeast strains, PLoS Genetics, 8, e1002570

El-Ashram, S., and Suo, X., 2017. Exploring the microbial community (microflora) associated with ovine Haemonchus contortus (macroflora) field strains, Scientific Reports, 7, 1-13

Elmahalawy, S.T., Halvarsson, P., Skarin, M., and Höglund, J., 2018. Droplet digital polymerase chain reaction (ddPCR) as a novel method for absolute quantification of major gastrointestinal nematodes in sheep, Veterinary Parasitology, 261, 1-8

Emery, D.L., Hunt, P.W., and Le Jambre, L.F., 2016. Haemonchus contortus: the then and now, and where to from here?, International Journal for Parasitology, 46, 755-769

Escribano, C., Saravia, A., Costa, M., Castells, D., Ciappesoni, G., RietCorrea, F., and Freire, T., 2019. Resistance to Haemonchus contortus in Corriedale sheep is associated to high parasite-specific IgA titer and a systemic Th2 immune response, Scientific Reports, 9, $1-10$

Estrada-Reyes, Z.M., Tsukahara, Y., Amadeu, R.R., Goetsch, A.L., Gipson, T.A., Sahlu, T., Puchala, R., Wang, Z., Hart, S.P., and Mateescu, R.G., 2019. Signatures of selection for resistance to Haemonchus contortus in sheep and goats, BMC Genomics, 20, 735

Eysker, M., Bakker, N., Kooyman, F., and Ploeger, H., 2005. The possibilities and limitations of evasive grazing as a control measure for parasitic gastroenteritis in small ruminants in temperate climates, Veterinary Parasitology, 129, 95-104

FAOSTAT, 2018. Food and Agriculture Organization of the United Nations. FAOSTAT: Statistics Database. 2018,

Fawzi, E.M., González-Sánchez, M.E., Corral, M.J., Alunda, J.M., and Cuquerella, M., 2015. Vaccination of lambs with the recombinant protein $\mathrm{rHc} 23$ elicits significant protection against Haemonchus contortus challenge, Veterinary Parasitology, 211, 54-59

Fernandes, M.A.M., Salgado, J.A., Peres, M.T.P., Campos, K.F.D., Molento, M.B., and Monteiro, A.L.G., 2019. Can the strategies for endoparasite control affect the productivity of lamb production systems on pastures?, Revista Brasileira de Zootecnia, 48,

Ferreira, J.B., Sotomaior, C.S., Bezerra, A.C.D.S., da Silva, W.E., Leite, J.H.G.M., de Sousa, J.E.R., Biz, J.d.F.F., and Façanha, D.A.E., 2019. Sensitivity and specificity of the FAMACHAC system in tropical hair sheep, Tropical Animal Health and Production, 51, 1767-1771

Fetene, A., and Amante, M., 2019. Alternative to Synthetic Anthelminthic to Prevent and Control Gastro Intestinal Parasite in Sheep and Goat, American-Eurasian Journal of Scientific Research, $14,06-14$

Getachew, T., Dorchies, P., and Jacquiet, P., 2007. Trends and challenges in the effective and sustainable control of Haemonchus contortus infection in sheep. Review, Parasite, 14, 3-14

Gilleard, J., and Redman, E., 2016. Genetic diversity and population structure of Haemonchus contortus. Advances in Parasitology, 2016, (Elsevier), 31-68

Goel, V., Singla, L.D., and Choudhury, D., 2020. Cuminaldehyde induces oxidative stress-mediated physical damage and death of Haemonchus contortus, Biomedicine \& Pharmacotherapy, 130, 110411

González-Garduño, R., López-Arellano, M., Mendoza-de Gives, P., Torres-Hernández, G., and Arece-García, J., 2018. Immune response in Blackbelly lambs to Haemonchus contortus and Trichostrongylus colubriformis mixed infection in a hot and humid climate, Tropical Biomedicine, 35, 696-708

Gowane, G., Swarnkar, C., Misra, S., Kumar, R., Kumar, A., Singh, D., and Prince, L., 2020. Selecting sheep for Haemonchus contortus resistance and susceptibility: Flock dynamics and genetic architecture, Research in Veterinary Science, 132, 116-126 
Greer, A., Kenyon, F., Bartley, D., Jackson, E., Gordon, Y., Donnan, A., McBean, D., and Jackson, F., 2009. Development and field evaluation of a decision support model for anthelmintic treatments as part of a targeted selective treatment (TST) regime in lambs, Veterinary Parasitology, 164, 12-20

Hassan, N.M., Aboelsoued, D., Farag, T.K., Hassan, S.E., and El Ezz, N.M.A., 2019. Assessment of Haemonchus contortus larval and adult somatic antigens in sero-diagnosis of haemonchosis in naturally infected sheep and goats, Journal of Parasitic Diseases, 43, 718-725

Hernandez, J., Hernández, A., Stear, M., Conde-Felipe, M., Rodríguez, E., Piedrafita, D., and González, J., 2016. Potential role for mucosal IgA in modulating Haemonchus contortus adult worm infection in sheep, Veterinary Parasitology, 223, 153-158

Höglund, J., Elmahalawy, S.T., Halvarsson, P., and Gustafsson, K., 2019. Detection of Haemonchus contortus on sheep farms increases using an enhanced sampling protocol combined with PCR based diagnostics, Veterinary Parasitology: X, 2, 100018

Iliev, P., Prelezov, P., Ivanov, A., Kirkova, Z., and Tonev, A., 2017. Clinical study of acute haemonchosis in lambs, Trakia Journal of Science, 15, 74-78

Irfan-ur-Rauf, T., Dar, S., Dar, J., Ganai, B., Chishti, M., and Fayaz, A., 2014. A brief study of morphology of Haemonchus contortus and its hematophagous behaviour, Global Veterinaria, 13, 960-965

Kandiwa, E., Nguarambuka, U., Chitate, F., Samkange, A., Madzingira, O., Mbiri, P., Bishi, A., and Mushonga, B., 2020. Production performance of sheep and goat breeds at a farm in a semi-arid region of Namibia, Tropical Animal Health and Production, 52, 2621-2629

Kellerová, P., Stuchlíková, L.R., Matoušková, P., Štěrbová, K., Lamka, J., Navrátilová, M., Vokřál, I., Szotáková, B., and Skálová, L., 2020. Sub-lethal doses of albendazole induce drug metabolizing enzymes and increase albendazole deactivation in Haemonchus contortus adults, Veterinary Research, 51, 1-17

Kenyon, F., and Jackson, F., 2012. Targeted flock/herd and individual ruminant treatment approaches, Veterinary Parasitology, 186, 10-17

Kho, E.A., Fernandes, J.N., Kotze, A.C., Fox, G.P., Lord, M., Beasley, A.M., Moore, S.S., and James, P.J., 2020. Visible-near infrared spectroscopy for detection of blood in sheep faeces, Journal of Near Infrared Spectroscopy. Accessed 9 June 2020 https://doi.org/ 10.1177/0967033520927519

Kuchai, J.A., Ahmad, F., Chishti, M.Z., Tak, H., Javid, A., Ahmad, S., and Rasool, M., 2012. A study on morphology and morphometry of Haemonchus contortus, Pakistan Journal of Zoology, 44, 1737-1741

Leathwick, D., Miller, C., Atkinson, D., Haack, N., Alexander, R., Oliver, A., Waghorn, T., Potter, J., and Sutherland, I., 2006. Drenching adult ewes: implications of anthelmintic treatments pre-and postlambing on the development of anthelmintic resistance, New Zealand Veterinary Journal, 54, 297-304

Liu, X.-Y., Chang, F.-F., Zhao, T.-Y., Huang, H.-Y., Li, F.-D., Wang, F., Wang, B.-B., Wang, F.-H., Liu, Q., and Luo, Q.-H., 2020. Biological control of sheep gastrointestinal nematode in three feeding systems in Northern China by using powder drug with nematophagous fungi, Biocontrol Science and Technology, 30, 701-715

Lyndal-Murphy, M., Ehrlich, W., and Mayer, D., 2014. Anthelmintic resistance in ovine gastrointestinal nematodes in inland southern Queensland, Australian Veterinary Journal, 92, 415-420

Macarthur, F., Kahn, L., and Windon, R., 2014. The influence of dietary manipulations and gastrointestinal nematodes on twin-bearing merino ewes and determinants of lamb survival, Livestock Science, $167,342-352$

Maestrini, M., Tava, A., Mancini, S., Tedesco, D., and Perrucci, S., 2020. In Vitro Anthelmintic Activity of Saponins from Medicago spp. against Sheep Gastrointestinal Nematodes, Molecules, 25, 242
Mahieu, M., and Aumont, G., 2009. Effects of sheep and cattle alternate grazing on sheep parasitism and production, Tropical Animal Health and Production, 41, 229-239

Mahmood, O.I., Muhsin, S.N., and Hussein, M., 2019. Morphological Diagnosis for Some Eggs of Gastrointestinal Nematodes from Sheep, Tikrit Journal for Agricultural Sciences, 19, 6-9

Mata-Padrino, D.J., Belesky, D.P., Crawford, C.D., Walsh, B., MacAdam, J.W., and Bowdridge, S.A., 2019. Effects of grazing birdsfoot trefoil-enriched pasture on managing Haemonchus contortus infection in Suffolk crossbred lambs, Journal of Animal Science, 97, 172-183

Melnychuk, V., 2019. Features of seasonal dynamics of sheep Haemonchosis in the territory of Zaporizhzhya region, Ukrainian Journal of Veterinary and Agricultural Sciences, 2, 7-11

Mohapatra, A., Shinde, A.K., and Singh, R., 2019. Sheep milk: a pertinent functional food, Small Ruminant Research, 181, 6-11

Mravčáková, D., Komáromyová, M., Babják, M., Urda Dolinská, M., Königová, A., Petrič, D., Čobanová, K., Ślusarczyk, S., Cieslak, A., and Várady, M., 2020. Anthelmintic Activity of Wormwood (Artemisia absinthium L.) and Mallow (Malva sylvestris L.) against Haemonchus contortus in Sheep, Animals, 10, 219

Mushonga, B., Habumugisha, D., Kandiwa, E., Madzingira, O., Samkange, A., Segwagwe, B.E., and Jaja, I.F., 2018. Prevalence of Haemonchus contortus infections in sheep and goats in Nyagatare District, Rwanda, Journal of Veterinary Medicine, Accessed 6 Sep 2018 https://doi.org/10.1155/2018/3602081

Nahar, L., Sarder, M., Rahman, M., Begum, M., and Rahman, S., 2019. Vulvar flap morphology of Haemonchus contortus in naturally infected slaughtered goats in Northern area of Bangladesh, Bangladesh Journal of Veterinary Medicine (BJVM), 17, RM2RM2

Nguyen, L.T., Kurz, T., Preston, S., Brueckmann, H., Lungerich, B., Herath, H.D., Koehler, A.V., Wang, T., Skálová, L., and Jabbar, A., 2019. Phenotypic screening of the 'Kurz-box' of chemicals identifies two compounds (BLK127 and HBK4) with anthelmintic activity in vitro against parasitic larval stages of Haemonchus contortus, Parasites \& Vectors, 12, 191

Nisbet, A., Meeusen, E., González, J., and Piedrafita, D., 2016. Immunity to Haemonchus contortus and vaccine development. Advances in Parasitology, 2016, (Elsevier), 353-396

Nixon, S.A., Saez, N.J., Herzig, V., King, G.F., and Kotze, A.C., 2019. The antitrypanosomal diarylamidines, diminazene and pentamidine, show anthelmintic activity against Haemonchus contortus in vitro, Veterinary Parasitology, 270, 40-46

O'Connor, L.J., Walkden-Brown, S.W., and Kahn, L.P., 2006. Ecology of the free-living stages of major trichostrongylid parasites of sheep, Veterinary Parasitology, 142, 1-15

Palevich, N., Maclean, P., Baten, A., Scott, R., and Leathwick, D.M., 2019. The complete mitochondrial genome of the New Zealand parasitic roundworm Haemonchus contortus (Trichostrongyloidea: Haemonchidae) field strain NZ Hco NP, Mitochondrial DNA Part B, 4, 2208-2210

Paras, K.L., George, M.M., Vidyashankar, A.N., and Kaplan, R.M., 2018. Comparison of fecal egg counting methods in four livestock species, Veterinary Parasitology, 257, 21-27

Pathak, A., Dutta, N., Banerjee, P., Goswami, T., and Sharma, K., 2016. Effect of condensed tannins supplementation through leaf meal mixture on voluntary feed intake, immune response and worm burden in Haemonchus contortus infected sheep, Journal of Parasitic Diseases, 40, $100-105$

Paul, T.K., Rahman, M.K., Haider, M.S., and Saha, S.S., 2020. Fatal haemonchosis (H. contortus) in Garole sheep at coastal region in Bangladesh, Research in Agriculture Livestock and Fisheries, 7, 107-112

Pinto, N., Gaspar, E., Minho, A., Domingues, R., de Moura, M., Junior, A., Capella, G., Dos Santos, P., da Costa, C., and Leite, F., 2020. 
Saccharomyces cerevisiae (YT001) supplementation for the control of Haemonchus contortus and modulation of the immune response of sheep, Beneficial Microbes, 11, 175-181

Prashanth, V., Kiran, H., Rupner, R.K., Patil, S., and Prakash, V., 2020. The "FAMACHA" Chart-An Alternate to Manage Haemonchosis in Small Ruminants-A Review Article, International Journal of Current Microbiology and Applied Sciences, 9, 1908-1913

Rehman, A., Jingdong, L., Chandio, A.A., and Hussain, I., 2017. Livestock production and population census in Pakistan: Determining their relationship with agricultural GDP using econometric analysis, Information Processing in Agriculture, 4, 168-177

Robinson, N., Piedrafita, D., Snibson, K., Harrison, P., and Meeusen, E.N., 2010. Immune cell kinetics in the ovine abomasal mucosa following hyperimmunization and challenge with Haemonchus contortus, Veterinary Research, 41, 37

Rocha, R., Bricarello, P., Silva, M., Houdijk, J., Almeida, F., Cardia, D., and Amarante, A.F.T.d., 2011. Influence of protein supplementation during late pregnancy and lactation on the resistance of Santa Ines and Ile de France ewes to Haemonchus contortus, Veterinary Parasitology, 181, 229-238

Roeber, F., Jex, A.R., and Gasser, R.B., 2013a. Advances in the diagnosis of key gastrointestinal nematode infections of livestock, with an emphasis on small ruminants, Biotechnology Advances, 31, 11351152

Roeber, F., Jex, A.R., and Gasser, R.B., 2013b. Impact of gastrointestinal parasitic nematodes of sheep, and the role of advanced molecular tools for exploring epidemiology and drug resistance-an Australian perspective, Parasites \& Vectors, 6, 153

Rose, H., Caminade, C., Bolajoko, M.B., Phelan, P., van Dijk, J., Baylis, M., Williams, D., and Morgan, E.R., 2016. Climate-driven changes to the spatio-temporal distribution of the parasitic nematode, Haemonchus contortus, in sheep in Europe, Global Change Biology, 22, 1271-1285

Ruiz-Huidobro, C., Sagot, L., Lugagne, S., Huang, Y., Milhes, M., Bordes, L., Prévot, F., Grisez, C., Gautier, D., and Valadier, C., 2019. Cell grazing and Haemonchus contortus control in sheep: lessons from a two-year study in temperate Western Europe, Scientific Reports, 9, 1-9

Saccareau, M., Sallé, G., Robert-Granié, C., Duchemin, T., Jacquiet, P., Blanchard, A., Cabaret, J., and Moreno, C.R., 2017. Meta-analysis of the parasitic phase traits of Haemonchus contortus infection in sheep, Parasites \& Vectors, 10, 201

Sakkas, P., Jones, L.A., Houdijk, J.G., Athanasiadou, S., Knox, D.P., and Kyriazakis, I., 2013. Leucine and methionine deficiency impairs immunity to gastrointestinal parasites during lactation, British Journal of Nutrition, 109, 273-282

Salgado, J., Cruz, L., Rocha, L., Sotomaior, C., Borges, T., and Santos, C., 2019. Implication of the fecal egg count reduction test (FECRT) in sheep for better use of available drugs, Revista brasileira de parasitologia veterinaria $=$ Brazilian Journal of Veterinary Parasitology, 28, 700-707

Sallé, G., Doyle, S., Cortet, J., Cabaret, J., Berriman, M., Holroyd, N., and Cotton, J., 2019. The global diversity of Haemonchus contortus is shaped by human intervention and climate, Nature Communications, 10, 1-14

Sambodo, P., Prastowo, J., Indarjulianto, S., and Kurniasih, K., 2018. MORPHOLOGY AND MORPHOMETRY OF Haemonchus contortus IN GOATS IN YOGYAKARTA, INDONESIA, Jurnal Kedokteran Hewan-Indonesian Journal of Veterinary Sciences, 12, $62-65$

Saminathan, M., Gopalakrishnan, A., Latchumikanthan, A., Milton, A., Aravind, M., Dhama, K., and Singh, R., 2015. Histopathological and parasitological study of blood-sucking Haemonchus contortus infection in sheep, Advances in Animal and Veterinary Sciences, 3, 99-108
Sargison, N.D., Redman, E., Morrison, A.A., Bartley, D.J., Jackson, F., Hoberg, E., and Gilleard, J.S., 2019. Mating barriers between genetically divergent strains of the parasitic nematode Haemonchus contortus suggest incipient speciation, International Journal for Parasitology, 49, 531-540

Schwarz, E.M., Korhonen, P.K., Campbell, B.E., Young, N.D., Jex, A.R., Jabbar, A., Hall, R.S., Mondal, A., Howe, A.C., and Pell, J., 2013. The genome and developmental transcriptome of the strongylid nematode Haemonchus contortus, Genome Biology, 14, R89

Schweizer, N.M., Foster, D.M., Knox, W.B., Sylvester, H.J., and Anderson, K.L., 2016. Single vs. double dose of copper oxide wire particles (COWP) for treatment of anthelmintic resistant Haemonchus contortus in weanling lambs, Veterinary Parasitology, 229, 68-72

Sinott, M., de Castro, L.D., Leite, F., Gallina, T., De-Souza, M., Santos, D., and Leite, F., 2016. Larvicidal activity of Bacillus circulans against the gastrointestinal nematode Haemonchus contortus in sheep, Journal of Helminthology, 90, 68-73

Storey, B.E., Williamson, L.H., Howell, S.B., Terrill, T.H., Berghaus, R., Vidyashankar, A.N., and Kaplan, R.M., 2017. Validation of the FAMACHA@ system in South American camelids, Veterinary Parasitology, 243, 85-91

Swarnkar, C., and Singh, D., 2018. Haematological variations in visually anaemic sheep naturally infected with Haemonchus contortus in farm conditions at arid Rajasthan, Indian Journal of Animal Sciences, 88, 34-38

Swarnkar, C., and Singh, D., 2020. Rhythmicity in thermal humidity index and regulation of Haemonchus contortus in sheep of semiarid tropical Rajasthan, Biological Rhythm Research, 51, 58-66

Taylor, M., Coop, R., and Wall, R., 2007. Veterinary Parasitology. Blacwell, Science (3rd edn), UK, 475-484

Terrill, T.H., Miller, J.E., Burke, J.M., Mosjidis, J.A., and Kaplan, R.M., 2012. Experiences with integrated concepts for the control of Haemonchus contortus in sheep and goats in the United States, Veterinary Parasitology, 186, 28-37

Tesfaheywet, Z., and Murga, S., 2019. Prevalence, species composition and worm burden of abomasal nematodes of small ruminants slaughtered in Hawassa, Southern Ethiopia, African Journal of Food, Agriculture, Nutrition and Development, 19, 14916-14931

Tian, X., Lu, M., Jia, C., Bu, Y., Aimulajiang, K., Zhang, Y., Li, C., Yan, R., Xu, L., and Song, X., 2020. Haemonchus contortus transthyretin domain-containing protein (HcTTR): a promising vaccine candidate against Haemonchus contortus infection, Veterinary Parasitology, 279,109045

Troell, K., Engström, A., Morrison, D.A., Mattsson, J.G., and Höglund, J., 2006. Global patterns reveal strong population structure in Haemonchus contortus, a nematode parasite of domesticated ruminants, International Journal for Parasitology, 36, 1305-1316

Vohra, S., Singh, S., and Sangwan, A.K., 2020. Epidemiology of Gastrointestinal Helminths of Sheep in Aeolian Plains of Haryana, Journal of Animal Research, 10, 47-52

Wang, C., Li, F., Zhang, Z., Yang, X., Ahmad, A.A., Li, X., Du, A., and Hu, M., 2017. Recent research progress in China on Haemonchus contortus, Frontiers in Microbiology, 8, 1509

Whitley, N.C., Oh, S.-H., Lee, S.J., Schoenian, S., Kaplan, R., Storey, B., Terrill, T., Mobini, S., Burke, J., and Miller, J., 2014. Impact of integrated gastrointestinal nematode management training for US goat and sheep producers, Veterinary Parasitology, 200, 271-275

Widiarso, B.P., Kurniasih, K., Prastowo, J., and Nurcahyo, W., 2018. Morphology and morphometry of Haemonchus contortus exposed to Gigantochloa apus crude aqueous extract, Veterinary World, 11, 921

Yin, F., Gasser, R.B., Li, F., Bao, M., Huang, W., Zou, F., Zhao, G., Wang, C., Yang, X., and Zhou, Y., 2016. Population structure of Haemonchus contortus from seven geographical regions in China, 
determined on the basis of microsatellite markers, Parasites \& Vectors, 9, 586

Zajac, A.M., and Garza, J., 2020. Biology, Epidemiology, and Control of Gastrointestinal Nematodes of Small Ruminants, Veterinary Clinics: Food Animal Practice, 36, 73-87

Zamilpa, A., García-Alanís, C., López-Arellano, M., HernándezVelázquez, V., Valladares-Cisneros, M., Salinas-Sánchez, D., and Mendoza-de Gives, P., 2019. In vitro nematicidal effect of Chenopodium ambrosioides and Castela tortuosa n-hexane extracts against Haemonchus contortus (Nematoda) and their anthelmintic effect in gerbils, Journal of Helminthology, 93, 434-439

Zarlenga, D., Hoberg, E.P., and Tuo, W., 2016. The identification of Haemonchus species and diagnosis of haemonchosis. Advances in Parasitology, 2016, (Elsevier), 145-180

Publisher's note Springer Nature remains neutral with regard to jurisdictional claims in published maps and institutional affiliations. 